\title{
URANG BANJAR: TOLAK-TARIK DEMOKRASI DAN KEBUDAYAANNYA
}

\author{
M. Rifqinizamy Karsayuda ${ }^{0}$
}

Received Article: 20 Mei 2017

Accepted Article: 20 Juni 2017

\begin{abstract}
There are no general solutions to the problem of culturally divided countries. Every solutions will need to be costum tailored the features of each country. (Robert A Dahl)
\end{abstract}

\section{Key Words: Banjar Ethnic, Democration, Culture, South Kalimantan}

\section{A. Pendahuluan}

$\mathrm{K}$ alimantan Selatan (Kalsel) sering diidentikkan dengan Urang Banjar, sebutan bagi penduduk etnis Banjar yang mayoritas mendiami wilayah ini. Kendati dalam kajian etnik, pengkerdilan etnik menjadi "klaim" wilayah tertentu tidak dibenarkan, sebab etnik dapat menembus batas wilayah melalui migrasi anggotanya, termasuk migrasi kebudayaannya, Namun membedah Kalimantan Selatan dari kaca mata etnik Banjar juga tidaklah terlalu salah.

Melihat Kalsel dari sudut pandang Urang Banjar adalah metode pembedahan dengan sampel generalis, sebab Urang Banjar sebagai penduduk mayoritas memiliki banyak peran dalam ranah keKalsel-an itu, kendati banyak etnis lain yang memberikan kontribusi dalam ranah Kalsel tersebut. Walaupun dalam metode ini, peran etnik lain (terpaksa) dinihilkan.

Salah satu diskursus yang menarik tentang peran Urang Banjar di Kalsel ialah terkait dengan peranan mereka dalam kepemimpinan provinsi ini. Pasca otonomi daerah, sebagaimana daerah lainnya di Indonesia, semangat untuk menjadikan orang-orang lokal (baca: putra daerah) sebagai pemimpin daerah terjadi di Kalsel.

Sebagai etnik mayoritas, Urang Banjar mendominasi kursi tersebut di daerah ini. Dalam ranah kebudayaan, sering dipertanyakan seperti apakah kepemim pinan berbasis budaya Banjar itu? Dalam konteks Kalsel dan ke-Indonesiaan, sejauh manakah kepemimpinan berbasis budaya Banjar dapat diwujudkan, termasuk dalam era otonomi daerah sekarang ini?

Dua pertanyaan ini sulit dijawab atas alasan. Pertama, kepemimpinan bagi saya adalah domain individu, bukan komunal, sementara budaya adalah domain komunal, sehingga kepemimpinan budaya adalah istilah yang kabur. Kedua, kepemimpinan seseorang dipengaruhi oleh banyak hal, salah satunya adalah budaya yang membe sarkannya.

Pertanyaan-pertanyaan tersebut (da lam pandangan saya) hanya dapat dijawab dengan terlebih dahulu menjawab perta nyaan; Apa etnik Banjar itu?, kemudian mencari apa sesungguhnya yang menjadi inti kebudayaan etnik Banjar?

Jawaban atas dua pertanyaan tersebut akan dapat dijadikan acuan untuk mengukur budaya Banjar yang menjadi basis kepemimpinan Urang Banjar dengan pelbagai isu lainnya, termasuk isu-isu seputar ketatanegaraan.

Untuk itu dalam tulisan ini, penulis menyajikan isu ketatanegaraan yang di anggap relevan diukur dengan budaya, yaitu demokrasi. Demokrasi dipilih atas beberapa alasan pertama, demokrasi yang

\footnotetext{
${ }^{0}$ Penulis adalah dosen Fakultas Hukum Universitas Lambung Mangkurat, Kalimantan Selatan
} 
berintikan prinsip kedaulatan rakyat menjadi prinsip utama dalam penyelenggaraan

bernegara sebagaimana diatur dalam pasal 1 UUD 1945 yang berbunyi "Kedaulatan

berada ditangan rakyat dan dilaksanakan menurut undang-undang dasar".

Kedua, demokrasi yang juga membe rikan hak-hak kepada rakyat yang tidak diberikan oleh sistem lainnya. Untuk hal ini, belakangan dipraktekkan dengan kebijakan otonomi daerah dan pemilihan kepala daerah langsung. Dua isu yang amat dekat dengan masyarakat daerah, termasuk masyarakat Kalsel. Dalam bagian akhir tulisan ini akan dilihat bagaimana total-tarik kebudayaan Banjar dengan demokrasi.

\section{B. Banjar : Entitas Etnik atau Politik ?}

$\mathrm{M}$ enurut Ahmadi Hasan, masyarakat Banjar merupakan komunitas etnis atau kumpulan penduduk asli Kalimantan Selatan yang termasuk dalam kelompok Melayu Muda (terdiri dari etnik Melayu sebagai etnik dominan, kemudian ditambah dengan unsur Bukit, Ngaju dan Maayan) yang umumnya tinggal di sekitar pantai dan menganut agama Islam ${ }^{1}$.

Namun menurut Alfani Daud dalam disertasinya yang diterbitkan menjadi buku berjudul Islam dan Masyarakat Banjar, Etnik Banjar bukanlah entitas etnik yang homogen, di dalamnya berbaur pelbagai unsur etnik yang terlebih dahulu ada seperti unsur Melayu yang diyakini datang dari Sumatera, unsur Jawa melalui migrasi Empu Jatmika, serta unsur Dayak sebagai etnik yang sejak lama ada di tanah Kalimantan, sebelum munculnya Banjar².

Dalam Hikayat Bandjar yang ditulis oleh J.J.Ras, etnik Banjar terbagi atas tiga sub etnik, yaitu Banjar Kuala, Banjar Batang Banyu dan Banjar Pahuluan. Pembagian kepada tiga sub-etnik tersebut didasarkan atas asal-usul geografis dan kebudaya

\footnotetext{
Ahmadi Hasan, Adat Badamai : Interaksi Hukum Islam dan Hukum Adat dalam Masyarakat Banjar. Antasari Press, Banajarmasin, 2008, hlm 108-109.

${ }_{2}^{2}$ Alfani Daud, Islam dan Masyarakat Banjar : Diskripsi dan Analisa Kebudayaan Banjar, PT.Raja Grafindo Persada, Jakarta,hlm 25-38.

Page | 48
}

annya ${ }^{3}$. Dari pembagian atas tiga sub etnik tersebut dapat terlihat bahwa etnik Banjar terwujud atas heteroginitas yang cukup tinggi, bahkan sampai dengan ketiga sub etnik itu menyebut dirinya sebagai Banjar.

Penyatuan ketiga sub etnik berbeda wilayah itu menjadi Banjar dilatarbelakangi oleh penyatuan wilayah kekuasaan ketiga sub etnik tersebut di bawah Kesultanan Banjar. Menurut Ras, kata Banjar sendiri berasal dari kata Banjarmasih, yang umumnya untuk menyebut negeri Banjar masih, yaitu wilayah kesultanan Banjar yang dipimpin oleh seseorang bernama Masih. Menurut Ahmadi, Banjar sendiri mengan dung makna berderet-deret sebagai letak perumahan kampung pedukuhan atau desa di atas air sepanjang pinggir sungai ${ }^{4}$.

Dari abstraksi itu, proses pemben tukan etnik banjar lebih dominan dilator belakangi oleh aspek politik berupa penyatuan dalam suatu kesultanan diban ding aspek kultural. Pada masa penjajahan Belanda, etnik Banjar semakin dimaknai sebagai entitas politis, ketika ia dijadikan komunitas antagonis dari etnik Dayak. Politik penjajah Belanda menempatkan Banjar dan Dayak sebagai dua etnik yang berhadap-hadapan, setidaknya dibedakan dengan faktor agama.

Orang Dayak yang beragama Islam lebih senang dipanggil sebagai Urang Banjar, atau panggilan lain, seperti Urang Banjar Bakumpai daripada dipanggil Dayak. Di kalangan Urang Banjar, seorang Dayak yang beragama Islam disebut telah baba rasih, suatu istilah yang sangat diskriminatif, bahkan provokatif. Istilah itu (dapat dipas tikan) muncul pasca Banjar menjadi Islam, atau pasca masuknya Pangeran Samudera ke agama Islam dan menggantikan namanya menjadi Sultan Surian syah, beberapa waktu sebelum Belanda datang ke tanah ini sekitar abad $18 .^{5}$

Keterlibatan Belanda dalam pemben tukan entitas politik Banjar dapat dilihat dari catatan Davidson yang menyatakan bahwa, etnik Dayak sebagai entitas politik, bukan entitas etnik seperti layaknya etnik-etnik

\footnotetext{
JJ.Ras, Hikajat Banjar: A Study an Malay Historiography, The Hague, Martinus Nijhoff, 1968, hIm 439.

${ }^{4}$ Ahmadi, Op. Cit, hlm 106-107.

${ }^{5}$ Alfani, Op.Cit, hlm 48.
} 
lain $^{6}$. Istilah Dayak menurutnya baru dikenal setelah penjajah Belanda datang. Sebe lumnya apa yang kita kenal sebagai Dayak sekarang terdiri dari etnik-etnik kecil yang satu sama lain berbeda. Alfani Daud menyebut nama etnik-etnik itu di Kalimantan Selatan, seperti Bukit, Ngaju (Biaju) dan Lawangan. ${ }^{7}$ Di daerah Sabah dan Sarawak yang masuk menjadi bagian Malaysia, nama-nama etnik yang kita sebut Dayak itu antara lain adalah Melanau, Iban dan Bidayuh. Di negara tersebut, ketiga etnik itu tidak disebut sebagai Dayak. ${ }^{8}$

Davidson meneruskan tesisnya, bahwa Dayak "diciptakan" oleh penjajah Belanda. la diletakkan sebagai entitas antagonis atas Melayu dan Banjar. Melayu dan Banjar adalah dua komunitas yang intens melawan Belanda di Kalimantan, kebetulan keduanya didominasi oleh kaum muslimin. "Penciptaan" Dayak, menurut Davidson, ialah dengan menjadikan Dayak yang mulanya ber-religi etnik menjadi kristen dan proses itu disupport oleh Belanda dengan mendatangkan mission naris, mendirikan gereja, membangun sekolah calon missionaris dan seterusnya di wilayah pedalaman Kalimantan yang menjadi basis dari etnik-etnik yang kita sebut Dayak tadi ${ }^{9}$.

Dengan menggunakan kacamata Banjar sebagai entitas politik, bukan etnik, maka sulit didapat akar kebudayaan Banjar itu sendiri, melainkan kebudayaan yang sesungguhnya berasal dari tiga sub-etnik Banjar yang satu sama lain berbeda, kendati belakangan menjadi berbaur. Satusatunya nilai yang paling berpengaruh dalam pembauran kebudayaan tiga subetnik itu yang kemudian dianggap sebagai kebu dayaan etnik Banjar adalah nilai-nilai Islam yang amat berpengaruh di etnik ini ${ }^{10}$.

\footnotetext{
${ }^{6}$ Lihat Jamie S. Davidson, "Primitive" Politics : The Rise and Fall of the Dayak Unity Party in West Kalimantan, National University of Singapore, 2003. ${ }^{7}$ Ibid, hlm 32.

${ }^{8}$ Monthly Statistical Bulletin Sarawak, Department of Statistics Malaysia, Sarawak Branch, February 1998 dalam Nidzam Sulaiman dan Sabihah Osman, Kepemimpinan Melayu Muslim Sarawak Mengharungi Abad ke-21, Prosiiding Konferensi Borneo 2000, UNIMAS, hlm 360

${ }^{9}$ Ibid.

${ }_{10}$ Alfani menyatakan "tidak ada Urang Banjar yang tidak memeluk Islam". Lihat Alfani, Op.Cit, hlm 542.

Urang Banjar
}

Alfani menggambarkan ajaran Islam mampu mengubah bahkan menggantikan budaya lama sub-etnik Banjar menjadi budaya baru. Budaya aruh tahun yang biasa dilaksanakan pada masa kerajaan Nagara dipa dan Nagaradaha yang beragama Hindu digantikan dengan aruh mulud, kepercayaan terhadap hal-hal ghaib dikoneksikan dengan rukun iman dalam kitab parukunan yang menjadi pegangan Urang Banjar, sehingga makhluk gaib yang dahulu dianggap keramat, pasca masuknya Islam dianggap sebagai bagian dari sesuatu yang wajib dipercayai, namun bukan untuk disembah. ${ }^{11}$

\section{Karakter Budaya Banjar dan Demokrasi}

$\mathrm{D}$ ari beberapa karakter budaya Banjar, hasil pencampuran budaya asal tiga sub-etnik dengan nilai-nilai Islam didapati beberapa budaya Banjar yang prodemokrasi, namun terdapat pula beberapa karakter budaya Banjar yang dianggap kurang mendukung proses demokratisasi.

\section{a. Budaya Banjar Pro demokrasi}

$\mathrm{B}$ eberapa budaya Banjar yang sejalan, bahkan dapat memperkuat demokra tisasi antara lain ;

\section{a) Kemampuan "mengontrol" ketidak adilan}

$\mathrm{S}$ ejarah panjang Urang Banjar menun jukkan bahwa kemampuan mela kukan kontrol oleh Urang Banjar atas ketidakadilan/kedhaliman. Pada masa kera jaan Banjar terdapat sekurang-kurangnya beberapa fakta sejarah yang menunjukkan adanya penentangan oleh masyarakat Banjar, yang dapat dimaknai sebagai kemampuan kontrol Urang Banjar.

Beberapa penentangan tersebut antaranya oleh Jalil dan kawan-kawannya atau biasa disebut dengan Gerakan Jalil terjadi pada pertengahan abad ke-19 di Banua Lima, sebuah daerah kerajaan

\footnotetext{
${ }^{11} \mathrm{lbid}, \mathrm{hlm} 518$
} 
Banjar yang meliputi daerah Negara, Alabio, Sungai Banar, Amuntai dan Kelua. ${ }^{12}, 13$

Gerakan ini muncul sebagai reaksi keatas pelbagai dasar yang dibuat oleh kepala daerah Banua Lima pada masa itu, Kyai Adipati Danuraja yang memerintah dengan sifat autoritarian dan penuh dengan penindasan. ${ }^{14}$

Selain gerakan Jalil, pertentangan juga dapat dilihat dari munculnya Gerakan Petani Tambai pada abad kesembilan pada masa pemerintahan Sultan Tamjidillah. Nama Tambai diambil dari nama kampung di sekitar wilayah Tapin, sebelah Selatan Kalimantan Selatan.

Gerakan ini muncul sebagai reaksi atas pengangkatan Sultan Tamjidillah sebagai Sultan Banjar yang merupakan campur tangan dari pihak Belanda pada masa itu. Tamjidillah mempunyai perilaku yang tidak mencerminkan perilaku keba nyakan bangsawan dan rakyat Banjar yang sangat memegang tinggi ajaran agama Islam. la lebih suka mengejar kenikmatan hidup antara orang Eropa di Banjarmasin. la juga terbiasa dengan minuman keras yang bertentangan dengan ajaran agama Islam ${ }^{15}$. Setelah Indonesia merdeka, masyarakat Kalimantan Selatan masih mesti berjuang mempertahankan Indonesia daripada keinginan Belanda untuk mengambil kembali Indonesia sebagai wilayah jajahan nya. Perjuangan itu merupakan bentuk penentangan masyarakat Kalimantan Se latan berikutnya. Setidak-tidaknya ada dua fakta sejarah yang menunjukkan hal itu, iaitu pertempuran pada 9 November 1945 untuk mengusir Belanda di sekitar Banjarmasin dan Proklamasi 17 Mei 1949 yang dilakukan oleh Hasan Basry dan kawan-kawan yang menyatakan bahawa wilayah Kalimantan Selatan ialah sebagian dari Indonesia. Sebelumnya Kalimantan

\footnotetext{
${ }^{12}$ Husni, Penembahan Muda Aling Datu Muning Studi Kasus tentang Kekuasaan Masyarakat Banjar, Pemerintah Daerah Tapin, 2002, hlm 33.

${ }^{13}$ Pada masa sekarang ini Banua Lima terdiri dari lima Kabupaten, iaitu HSS, HSU, HST, Tapin dan Tabalong. Sejak tahun 2002 lebih dikenal dengan nama Banua Anam, sebab Kabupaten HSU dimekarkan menjadi dua kabupaten yang melahirkan Kabupaten Balangan.

${ }^{14}$ Helius Sjamsuddin Pegustian dan Temenggung Akar Sosial, Politik, Etnis dan Dinasti, Penentangan di Kalimantan Selatan dan Tengah 1859-1906, Balai Pustaka, Jakarta, 2001, hlm 126.

${ }^{15}$ Husni, Loc. Cit, hlm 40.

Page | 50
}

Selatan dan Indonesia dipisahkan oleh Belanda melalui perjanjian Linggarjati dengan menjadikan kedua-duanya sebagai negara bahagian sahaja di bawah Republik Indonesia Serikat (RIS).

Setelah Belanda tidak lagi menjajah, rakyat Kalimantan Selatan tetap melakukan penentangan terhadap pemerintahan Soe karno yang dinilai tidak memperlakukan wilayah ini secara adil. Penentangan itu terlihat dari gerakan Negara Islam Indonesia (NII) yang dipimpin oleh Ibnu Hajar. Banyak pandangan yang memaknai gerakan lbnu Hajar ini, antaranya ia dimaknakan sebagai sikap inkonsistensi (tidak konsisten) masyarakat Kalimantan Selatan terhadap negara Kesatuan Republik Indonesia. Hal ini disebabkan gerakan ini hendak memi sahkan diri dari Indonesia dengan mendirikan NII. Namun kalau dilihat lebih jauh, gerakan Ibnu Hajar sesungguhnya hanyalah menggunakan NII sebagai alat perjuangan, namun bukan merupakan alat untuk mencapai kemerdekaan atau lepas dari Indonesia.

Dalam catatan Humaidy, masyarakat Banjar memiliki budaya yang mengandungi semangat penentangan. Humaidy secara lebih lengkap mengatakan bahwa: "Tradisi penentangan dapat dimaknai sebagai oposisi yang merupakan salah satu nilai demokrasi juga, yang dalam masyarakat Banjar sudah tumbuh sejak lama. Dalam sejarah Banjar sentiasa muncul kekuatan pembangkang yang berusaha mengawal pergerakkan sebuah rejim yang berkuasa. Kedudukan kekuatan oposisi ini dapat dilihat dari sejak berdirinya kerajaan Banjar sehingga keruntuhannya, bahkan terus berlanjutan sampai awal kemerdekaan. Ketika penguasa kerajaan Banjar dipegang oleh Pangeran Tumenggung, muncul Sultan Suriansyah (1526-1545) menentangnya. Ketika Amirullah Bagus berkuasa (1660 1663), Pangeran Adipati Anum (1663-1679) melakukan kudeta. Sebaliknya, ketika Adipati Anum berkuasa Amirullah Bagus (1680-1700), ganti mengkudeta. Ketika Tahmidullah II (1761-1801) berkuasa, Pa ngeran Amir menentang dengan 3000 orang bala tentara Bugis. Namun sayang, Pangeran Amir kalah dan kemudian dibuang ke Sailon. Ketika Sultan Tamjidillah (1857-1859) berkuasa menjadi "boneka"

Urang Banjar 
penjajah Belanda, Pangeran Hidayatullah dan Pangeran Antasari yang kuat menantangnya. Ketika memasuki zaman kemerdekaan Hasan Basry setia menginte grasikan Kalimantan Selatan ke dalam Negara Kesatuan Republik Indonesia, muncul Ibnu Hajar menentang untuk mendirikan negara sendiri berlandaskan Islam". ${ }^{16}$

Dalam demokrasi, pengawasan oleh rakyat atas wakil yang telah mereka berikan mandat adalah keharusan. Pemberian mandat tanpa pengawasan adalah pemben tukan pemerintahan atau penyerahan hak yang (dapat) melahirkan kesewenangwenangan. Lord Acton melalui adagiumnya telah mengingatkan bahwa, setiap keku asaan berpotensi disalahgunakan ${ }^{17}$. Robert A Dahl memasukkan pelaksanaan penga wasan oleh rakyat atas penguasanya sebagai salah satu karakter dari demo krasi. $^{18}$

\section{b) Taat Aturan}

$\mathrm{H}$ ukum dalam arti peraturan yang tertulis sudah ada di masyarakat Banjar masa lalu. Undang-undang Sultan Adam (UUSA) adalah bukti otentik yang bersifat tertulis yang dibuat oleh Sultan Adam pada masa ia berkuasa sekitar tahun 1825-1857.

UUSA memberikan aturan yang berisi tentang hubungan masyarakat yang satu dengan yang lain, termasuk juga mengatur tentang hubungan hukum pemerintah dan masyarakatnya. Perlindungan hukum yang diatur dalam UUSA ini. Dalam UUSA ini juga terdapat lembaga peradilan, baik yang bersifat publik dan privat, termasuk fungsifungsi peradilan di lapangan hukum Islam layaknya peradilan agama kini.

Catatan Ahmadi Hasan, implementasi UUSA masa itu sangat baik. UUSA mampu menghadirkan hukum sebagai panglima yang berujung pada ketertiban masyarakat. Kendati kehadiran UUSA yang merupakan inisiatif penguasa, dalam hal ini Sultan

\footnotetext{
16 Humaidy, A, Budaya Banjar dan Nilai-Nilai Demokrasi, PSIK, Jakarta, 2000, hlm 9.

17 Adagium dimaksud ialah "Power tends to corrupts, Absolute power corrupt absolutely".

18 Robert A Dahl, On Democracy, edisi terjemahan, Yayasan Obor Indonesia, Jakarta, 2001, hlm 52-53.

Urang Banjar
}

masa itu, namun diikuti dengan baik oleh masyarakat kesultanan Banjar, termasuk masyarakat Banjar sekarang.

Keteraturan hanya dapat tercipta dengan adanya aturan dan kehendak masyarakat untuk tunduk pada aturan itu. Dengan adanya keteraturan, demokrasi dan kedaulatan rakyat dapat berjalan. Dalam suasana yang tak teratur, pemerintah dapat menjadi otoriter dan menghambat kedau latan rakyat itu sendiri. ${ }^{19}$

\section{c) Musyawarah}

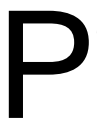

asal 21 UUSA menyatakan "Tiap-tiap kampung bilamana terjadi sengketa, maka diperintahkan untuk mendamai kan (mamatut) dengan tetuha kampung, bilamana tidak berhasil barulah dibawa kepada hakim". Pasal ini dan beberapa pasal lainnya seperti pasal 3, dan pasal 20, 29, 30 dst dalam UUSA menganut prinsip munsyawarah dan perdamaian dalam menyelesaikan pelbagai sengketa yang ada di masyarakat Banjar melalui mekanisme adat Badamai .

Disertasi Ahmadi Hasan tentang adat Badamai di masyarakat Banjar, menggam barkan dengan jelas betapa lembaga Badamai menjadi media yang efektif sebagai alternatif penyelesaian sengketa (alternative dispute resolution), selain peradilan.

Ghazali menyatakan bahwa adat Badamai dalam masyarakat Banjar me rupakan implementasi nilai-nilai Islam yang selalu mengajarkan jalan damai atau ishlah dalam menyelesaikan suatu perseng ketaan $^{21}$. Badamai bukan hanya digunakan dalam lapangan hukum perdata, seperti kawin-cerai, waris, pisah ranjang (baram bangan), utang-piutang dan sebagainya,

\footnotetext{
${ }^{19} \mathrm{Ibid}, \mathrm{hlm} 201$.

20 Abdurrahman, Beberapa Catatan tentang UndangUndang Sultan Adam Ditinjau dari Perspektif Hukum, Hukum Islam dan Hukum Adat Banjar, (Makalah), Simposium tentang UUUSA, Fakultas Hukum Unlam, Banjarmasin, 1984.

21 Gazali Usman, Kerajaan Banjar: Sejarah Perkembangan Politik, Ekonomi, Perdagangan dan Agama Islam, Universitas Lambung Mangkurat, Banjarmasin, 1994, hlm 11.
}

Page | 51 
namun juga digunakan dalam lapangan hukum pidana, seperti perkelahian dan pembunuhan. Dalam konteks kekinian implementasi adat Badamai juga dapat dilihat dari penyelesaian perkara tapal batas daerah (yang berdimensi administratif) ${ }^{22}$.

\section{b. Budaya Banjar Kontra demokrasi}

$\longrightarrow$ elain beberapa budaya Banjar yang menyokong demokrasi. Terdapat be berapa budaya Banjar yang asimetris dengan nilai-nilai demokrasi. Budaya ter sebut, antara lain;

\section{a) Budaya Patrimonial}

$\mathrm{S}$ alah satu karakter budaya Banjar adalah adanya semangat untuk berkumpul dalam satu komunitas bernama bubuhan. Di masa lalu, bubuhan terdiri dari kumpulan penduduk yang jumlahnya tidak terlalu besar. Di setiap bubuhan terdapat kepala bubuhan, yaitu orang yang dianggap paling berpengaruh dan sakti di lingkungannya.

Setelah masyarakat Banjar beragama Islam, konsep kepala bubuhan bergeser dari yang sakti menjadi yang alim. Urang Alim dianggap bukan hanya memiliki kelebihan dalam ilmu agama, namun juga dalam ilmu-ilmu ghaib. Selanjutnya Urang alim dan ketrunannya selalu dijadikan patrone (pa nutan) di kalangan bubuhannya.

Etnik Banjar yang (terlanjur) berkiblat pada patron tertentu, sangat sulit melihat patronnya secara objektif. Sebagai contoh, di masyarakat Banjar orang yang memiliki ilmu agama,namun bukan keturunan Urang alim kurang dihormati dibanding orang yang memiliki ilmu agama, tetapi ia merupakan keturunan Urang alim, walaupun ilmu yang dimiliknya lebih rendah dibanding orang yang pertama ${ }^{23}$.

22 Disertasi Ahmadi Hasan memberikan gambaran beberapa kasus yang hingga kini masih dapat diselesaikan dengan adat Badamai. Keterlibatan para pihak dalam adat Badamai, tidak terbatas pada masyarakat umum,namun juga para pejabat daerah sampai aparatur hukum. Lihat dalam Ahmadi, Op.Cit, hIm 223-273.

${ }^{23}$ Alfani, Op.Cit, hlm 564-568.

Page | 52
Belakangan, orang yang berasal dar kalangan elite daerah, termasuk keturu nannya jauh lebih dihormati dan dipercaya dibanding orang-orang dari kalangan proletarian, walaupun mereka memiliki kapasitas dan kemampuan yang memadai.

\section{b) Karakter Pragmatis}

$\mathrm{M}$ asyarakat etnik Banjar dikenal juga sebagai masyarakat dagang. $\mathrm{Ke}$ mampuan berdagang Urang Banjar seiring dengan migrasi mereka ke berbagai wilayah di Kalimantan, utamanya tengah dan timur. Sebagai masyarakat pedagang, Urang Banjar terbiasa menggunakan logika untung dan rugi dalam menyelesaikan pelbagai masalah. Ungkapan seperti "kada jadi baras jua"misalnya, mengindikasikan betapa Urang Banjar sangat menge depankan hitung-hitungan tertentu sebelum ikut terlibat dalam sutau persoalan. Dengan kata lain, hal-hal yang bersifat immaterial kUrang mendapat tempat bagi masyarakat Banjar, sebaliknya pengorbanan yang dapat merugikan mereka secara materiil sangat dihindari oleh masyarakat ini.

Pragmatisme demikian berakibat buruk pada proses demokratisasi. Hal ini dikarenakan pemberian kedaulatan rakyat yang menjadi ruh demokrasi didasarkan atas kepentingan untung-rugi semata. Patronase dalam pengertian yang membabi buta dan pragmatism berpolitik adalah racun demokrasi, sebab keduanya menja dikan proses berdemokrasi didasarkan atas kebutuhan pribadi yang bersifat jangka pendek, bukan akan kepentingan bangsa/ negara.

\section{c. Pemimpin Kalsel: Urang Banjar atau ?}

D engan segala dialektika kebudaya annya, termasuk dengan demokrasi yang belakangan begitu penting dalam era perpolitikan dan otonomi daerah sekarang ini, muncul pertanyaan relevankah isu kepemimpinan Urang Banjar dalam konteks ke-Kalsel-an? Pertama, dalam kon teks hukum tata negara kekinian, khususnya terkait dengan kebijakan otonomi daerah, setiap daerah (provinsi, kabupaten/kota) diberikan dua macam urusan untuk mengelola daerahnya, yaitu

Urang Banjar 
urusan wajib dan urusan pilihan ${ }^{24}$. Jika urusan wajib daerah diberlakukan sama antara satu daerah dengan daerah lainnya, maka urusan pilihan yang diberikan bersifat sangat relatif bergantung kepada "kreati fitas" daerah masing-masing. Pasal 13 ayat (2) UU No.32 Tahun 2004 Tentang Pemerintahan Daerah menyatakan "Urusan pemerintahan provinsi yang bersifat pilihan meliputi urusan pemerintahan yang secara nyata ada dan berpotensi untuk mening katkan kesejahteraan masyarakat sesuai dengan kondisi, kekhasan, dan potensi unggulan daerah yang bersangkutan".

Seorang kepala daerah yang berasal dari daerah tersebut, disumsikan mem punyai kedekatan emosional dengan daerahnya, serta lebih memahami kekhasan daerahnya. Dalam konteks Kalsel, Urang Banjar memenuhi persyaratan ini, sebab mereka adalah mayoritas di daerah ini, baik dari jumlah, maupun sebaran penduduk yang mendiami provinsi ini. Senada dengan hal tersebut, dalam kewajiban daerah yang tercantum dalam pasal 22 disebutkan 15 kewajiban daerah, salah satunya adalah kewajiban untuk melestarikan nilai sosial dan budaya daerah. Kewajiban daerah adalah salah satu hal yang menjadi tugas pokok kepala daerah untuk melaksana kannya $^{25}$, sehingga seorang Banjar tentu lebih tepat melestarikan budaya banuanya dalam konteks ini dibanding orang luar Kalsel yang menjadi kepala daerah ini.

Kedua, kedudukan kepala daerah dalam konteks otonomi di negara kesatuan memiliki dua peran sekaligus. Pertama sebagai kepala daerah otonom dan kedua sebagai wakil pemerintah pusat di daerah. Sebagai kepala daerah otonom, seorang kepala daerah mengemban tugas desen tralisasi. Desentralisasi dalam pengertian lunak dapat dimaknai sebagai pengelolaan pemerintahan oleh pemerintah daerah sendiri, ia hadir atas dasar pelimpahan tugas dari pemerintah pusat ${ }^{26}$.

Dalam konteks desentralisasi ter sebut, kepala daerah mesti mengetahui

\footnotetext{
24 Lihat pasal 13 UU No.32 Tahun 2004 tentang Pemerintahan Daerah.

${ }^{25}$ Pasal 25 huruf e UU No.32 Tahun 2004 tentang Pemerintahan Daerah.

${ }^{26}$ Lihat pengertian desentralisasi dalam pasal $1 \mathrm{UU}$ No.32 Tahun 2004 tentang Pemerintahan Daerah.

Urang Banjar
}

benar potensi daerahnya. Kepala daerah yang berasal dari daerahnya (mestinya) lebih mengetahui hal-hal yang terkait dengan daerah dan rakyatnya. Disinilah urgensi Urang Banjar untuk memimpin Kalsel dibanding orang non-Banjar.

Ketiga, terkait dengan kekhasan dan desentralisasi tersebut, kepala daerah (siapapun orangnya) mesti dapat mem bangun komunikasi yang efektif dengan masyarakatya. Dalam konteks komunitas Banjar, hal tersebut dapat dilakukan dengan lebih baik oleh sesama Urang Banjar. Selain itu, budaya patronase yang selama ini melekat dengan Urang Banjar dapat diarahkan lebih linier dan terarah dengan kepemimpinan Urang Banjar untuk meng hadirkan Banua yang lebih baik.

\section{Penutup}

$\mathrm{K}$ epemimpinan Urang Banjar untuk Kalsel dalam beberapa waktu bela kangan ternyata lebih mampu memunculkan kekhasan daerah dalam tata kelola pemerintahan sebagaimana yang diharapkan UU No.32 Tahun 2004 di atas ${ }^{27}$. Kedepan, kepemimpinan Urang Banjar diharapkan bukan hanya mampu me ngangkat local contain dalam arti kebudayaan, namun dapat meningkatkan harkat provinsi ini dengan melakukan akselerasi keadilan dan kesejahteraan ber basis lokalitas.

Catatan lain dalam tolak tarik demokrasi, kebudayaan Banjar dan kepe mimpinan Urang Banjar ialah, bahwa pemimpin Kalsel yang berasal dari Urang Banjar seyogyanya mengembangkan aspek-aspek positif kebudayaan Banjar seperti keberanian diri untuk dikontrol, kemauan membuat aturan yang pro rakyat dan mengedepankan win-win solution dalam menyelesaikan masalah. Sebaliknya, pemim pin Kalsel yang berasal dari Urang Banjar jangan justru memanfaatkan aspekaspek negatif dalam budaya Banjar yang sangat patrone dan pragmatis dalam

\footnotetext{
27 Sebagai contoh pada masa kepemimpinan Ir.H.M.Said, kain sasirangan mendapat sokongan kebijakan sehingga dapat muncul menjadi primadona dan kekhasan Kal-sel.
} 
berpolitik, sebagai senjata "menaklukkan" rakyat. Bukankah kata Dahl, setiap masalah dalam setiap lokal ,baru dapat diselesaikan secara baik, jika (penyelesaiannya) menga $\mathrm{cu}$ dengan kearifan lokal masing-masing sebagai mana pembuka tulisan ini.

\section{Daftar Pustaka}

Abdurrahman.1984. Beberapa Catatan tentang Undang-Undang Sultan Adam Ditinjau dari Perspektif Hukum, Hukum Islam dan Hukum Adat Banjar. Simposium tentang UUUSA Fakultas Hukum Unlam: Banjarmasin.

Daud, Alfani. 1997. Islam dan Masyarakat Banjar : Diskripsi dan Analisa Kebudayaan Banjar. PT.Raja Grafindo Persada: Jakarta.

Humaidy, A. 2000. Budaya Banjar dan Nilai-Nilai Demokrasi. PSIK: Jakarta.

Hasan, Ahmadi. 2008. Adat Badamai : Interaksi Hukum Islam dan Hukum Adat dalam Masyarakat Banjar. Antasari Press: Banjarmasin.

Husni. 2002. Penembahan Muda Aling Datu Muning : Studi Kasus tentang Kekuasaan Masyarakat Banjar. Pemerintah Daerah Tapin: Banjarmasin.

JJ.Ras. 1968. Hikajat Banjar : A Study an Malay Historiography, The Hague. Martinus : Nijhoff.

Pegustian, Helius Sjamsuddin dan Temenggung. 2001. Akar Sosial, Politik, Etnis dan Dinasti, Penentangan di Kalimantan Selatan dan Tengah 1859-1906. Balai Pustaka: Jakarta.

Rober, A Dahl, 2001. On Democracy, edisi terjemahan. Yayasan Obor Indonesia: Jakarta.

S. Davidson, Jamie. 2003. "Primitive" Politics : The Rise and Fall of the Dayak Unity Party in West Kalimantan. National University of Singapore: Singapura.

Sulaiman, Nidzam dan Sabihah Osman. 2000. Kepemimpinan Melayu Muslim Sarawak Mengharungi Abad ke-21. Prosiiding Konferensi Borneo 2000 UNIMAS: Malaysia.

Usman, Gazali. 1994. Kerajaan Banjar: Sejarah Perkembangan Politik, Ekonomi, Perdagangan dan Agama Islam. Universitas Lambung Mangkurat: Banjarmasin. 